\title{
2004 年の強風災害の被害状況 \\ Summary of damage due to high winds in 2004
}

\author{
西村宏昭* \\ Hiroaki NISHIMURA
}

\section{1.はじめに}

2004 年にはこれまでの最多の台風がわが国に上陸 し, 各地で甚大な被害をもたらした。日本風工学会風 㷋害研究会では 2004 年の台風被害をまとめ, 報告書と して発行した ${ }^{1)}$ 。この報告書を作成した目的は, 被害 を記録し情報を共有することと，それを教訓として構 造物の強風被害の低減に結びつけることである。被害 がさまざまな種類の構造物に及んだことから, 当研究 会委員がそれぞれの専門分野ごとに被害の調查に当つ た。各委員は強風被害とその低減に関心をもっている が,被害の集約から被害低減の方策の立案, その害行, さらには耐風設計規基準の見直しまですべての段階で 力が及ぶものではない。とはいえ, 強風被害の低減に 貢献することこそが当研究会の役目であり，それは日 本風工学会の役目でもあろう。今回, 2004 年の台風被 害を振り返り, 強風災害の低減に向けて本会がなしう ることを改めて問い直すことで，日本風工学会会員の 間で問題意識を共有し, 総合的な力の結集でその問題 の解決を図る機会が与えられると期待できる。

ここでは, 2004 年の強風災害の被害状況を振り返る。 本稿の情報源は当研究会の報告書と日本建築学会強風 災害調査ワーキンググループ（主査；田村幸雄）がま とめた「2004 年の強風被害とその教訓」2)である。本 稿はそれらの被害調査をレビューする形式を採ってい る。詳細な情報はこれらの原文を参照していただきた い。これらの報告書の中には強風災害以外の被害の報 告も含まれているが，ここでは割愛した。

\section{2. 強風被害の集計}

日本損害保険協会の調査による歴代の高額保険金支 払状況を表 1 に示す。上位 10 位までに 2004 年に発生 した 3 つの台風災害が含まれているのが分かる。これ とは別に, 外国損害保険協会に加盟する保険会社やJA 共済, 全労済などの補償支払も存在し，この公表デー タが台風損害に対する支払保険金のすべてを表してい るものではないことに注意する必要がある。現在のと ころ, 強風被害額の総計を集計する方法はわが国には 存在しない。しかし表 1 はその一部であるとしても台 風被害の大きさが分かるであろう。

2004 年度の自然災害による保険金支払総額は過去 最高の 7,400 億円以上に達した。大規模な自然災害に 備えて積み立てている「異常危険準備金」を取り崩し て対応を行った損保会社も多く, 召田は, 「大規模自然 災害が今後も頻発した場合, 損保会社の経営に与える 影響は甚大といえる」と述べている。

\section{表 1 歴代の高額保険金支払状況}

\begin{tabular}{|r||l|l|r||}
\hline \multicolumn{1}{|c|}{ 順位 } & \multicolumn{1}{|c|}{ 災害名 } & \multicolumn{1}{|c|}{ 発生年月日 } & \multicolumn{1}{|c|}{$\begin{array}{c}\text { 支払保険金 } \\
\text { (単位:億円) }\end{array}$} \\
\hline 1 & 台風 9119 号 & $1991.9 .26 \sim 28$ & 5,679 \\
\hline $\mathbf{2}$ & 台風 0418 号 & $\mathbf{2 0 0 4 . 9 . 4 \sim 8}$ & $\mathbf{3 , 8 2 3}$ \\
\hline 3 & 台風 9918 号 & $1999.9 .21 \sim 25$ & 3,147 \\
\hline 4 & 台風 9807 号 & 1998.9 .22 & 1,600 \\
\hline $\mathbf{5}$ & 台風 0423 号 & $\mathbf{2 0 0 4 . 1 0 . 2 0}$ & $\mathbf{1 , 2 9 2}$ \\
\hline $\mathbf{6}$ & 台風 0416 号 & $\mathbf{2 0 0 4 . 8 . 3 0 \sim 3 1}$ & $\mathbf{1 , 1 7 5}$ \\
\hline 7 & 2000 年9 月豪雨(愛知等) & $2000.9 .10 \sim 12$ & 1,030 \\
\hline 8 & 台風 9313 号 & 1993.9 .3 & 977 \\
\hline 9 & $\begin{array}{l}\text { 2000 年ひよ う災 (千葉, } \\
\text { 茨城) }\end{array}$ & 2000.5 .24 & 700 \\
\hline 10 & 台風 0514 号 & $2005.9 .4 \sim 7$ & 588 \\
\hline \hline
\end{tabular}

* 財団法人日本建築総合試験所

General Building Research Corporation 
河井, 召田は 2004 年の上陸台風の中で最も被害の大 きかった台風0418号の被害集計を表2のように行った。 河井らは「2004 年の台風と豪雨による死者の合計は 236 名に達し, 中越地震の死者 48 名の 5 倍近くに達し た。また, 浸水を含めた被害家屋も 27 万棟を超え, 中 越地震の 12 万棟の 2 倍以上に達した。2004 年の風水 害の被害の総計は中越地震の被害よりも大きかったこ とが分かる」と述べ, 台風被害の衝撃を決して軽視し ないように警告を発している。

表 2 台風 0418 号の地方別被害の集計

\begin{tabular}{|r|r|r|r|r|}
\hline \multirow{2}{*}{ 地方 } & \multicolumn{2}{|c|}{ 人的被害 } & \multicolumn{2}{|c|}{ 住家被害 } \\
\cline { 2 - 5 } & \multicolumn{1}{|c|}{ 死者 } & 負傷者 & 全半壊 & 一部損壊 \\
\hline 北海道 & 9 & 434 & 229 & 8450 \\
\hline 東北 & & 7 & & 325 \\
\hline 関東 & & 3 & & 2 \\
\hline 北陸 & & 31 & & 135 \\
\hline 中部 & 1 & 13 & & 68 \\
\hline 近畿 & & 119 & 5 & 81 \\
\hline 中国 & 32 & 352 & 409 & 18576 \\
\hline 四国 & 1 & 43 & 23 & 642 \\
\hline 九州 & 43 & 1003 & 666 & 28279 \\
\hline
\end{tabular}

\section{3．台風による構造物の強風被害}

\section{1 大スパン建築物の屋根の被害}

2004 年の台風シーズンでは, 大スパン建築物の屋根 の被害が多く見られた。これらの建築物の被害は，そ の周辺では目立った被害が発生していない状況で被害 が発生していることが多かった。河井, 西村, 松井, 曹は写真 1 に示す台風 0406 号の強風による, 滋賀県近 江八幡市内のホテルの屋根の飛散被害を調査した。こ の被害は $9 \mathrm{~m} \times 41 \mathrm{~m}$, 重さ約 7 トンの屋根が飛散して, 新幹線の架線に掛かり, 約 7 時間にわたつて新幹線の 運行を不通にしたものである。幸いにして人的被害は 発生しなかったが，この屋根が架線に乗った状況で新 幹線が突入すると大惨事は免れ得なかったであろう。 飛散した屋根は，既存の屋根の漏水を防ぐために既存 屋根の上に設置したもので，写真 2 に示す極めて強度 の低い金具を介した細いビスの引き抜き強度と, 屋根 の重量による浮き上がり抵抗を期待する稚拙な構法が 採用されていた。飛散した屋根は, 既存の構造体が存 在するので構造骨組ではなく，外装材とみなされるこ とにより，建築確認の義務は生じないと判断されてい た。

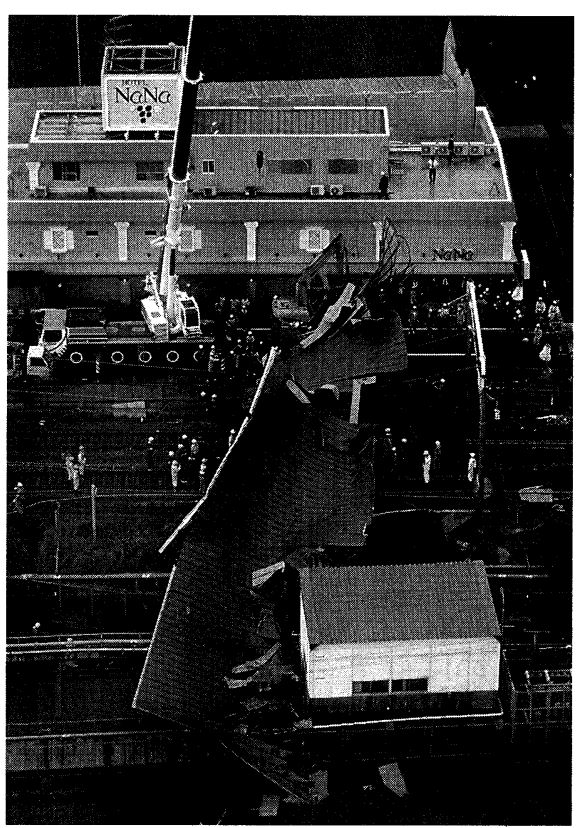

写真 1 ホテルの屋根の飛散（読売新聞社）

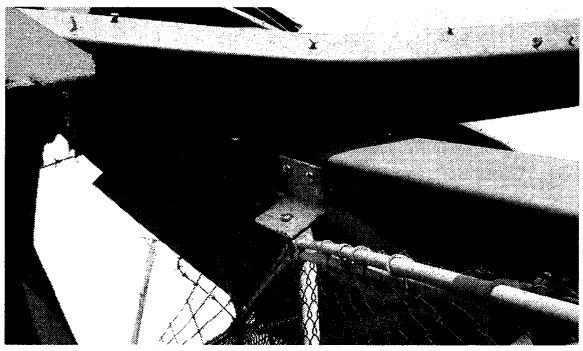

写真 2 飛散した屋根の固定金具

田村, 奥田, 西村, 谷池, 谷口, 池内は, 写真 3 に 示す兵庫県にある大型放射光実験施設 SPring-8 の断熱 二重折板屋根が強風で外周部から剥がれた被害を調査 した。SPring-8 は直径約 500m, 幅約 $28 \mathrm{~m}$ のドーナツ 状の平面をしており，高さは約 $10 \mathrm{~m}$ である。この屋根 はこの年 2 度の台風 0416 号と 0418 号で同様の被害を 受け，室内に漏水が生じて精密実験装置が壊れ大きい 被害が生じた。独立行政法人理化学研究所が被害原因 調査委員会を設置し，屋根の温度変動による上側金属 折板の熱伸縮によって接合ボルトに繰返し応力が掛か り，ボルトが金属疲労した（写真 4）ことを明らかに した。その原因は，繰り返し荷重がボルトに作用しな いように工夫されていたはずのボルトと鋼板製屋根間 のスライド機構が所定の性能を発揮しなかったことに よると推定された。 


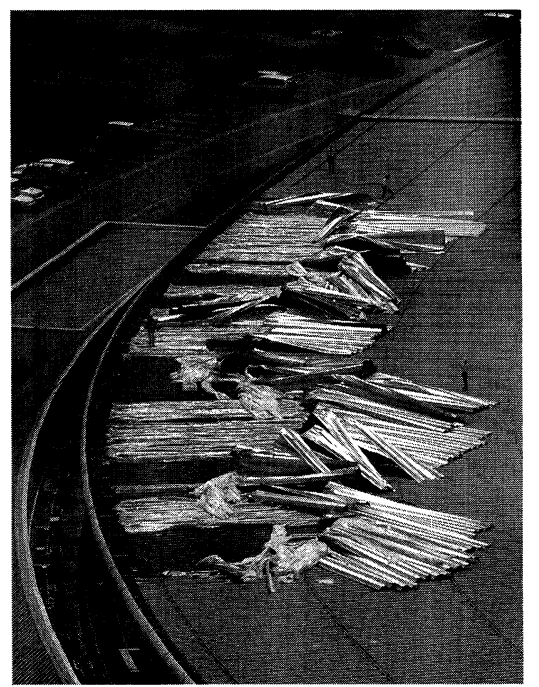

写真 3 SPring-8 の被害（台風 0418 号, 読売新聞社)

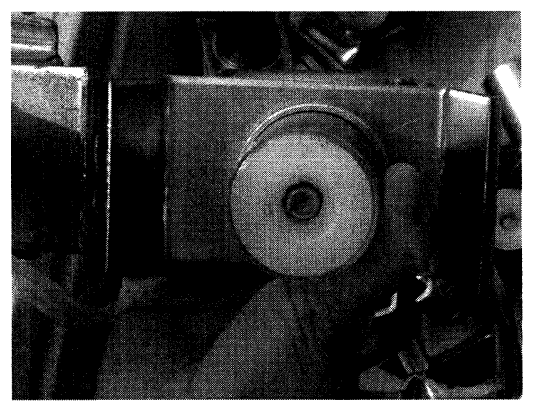

写真 4 SPring-8 の屋根の金属疲労により破断したボルト

SPring-8 と同じ構法の他の建築物の被害も西村によ り報告された。写真 5 は台風 0423 号による神戸市内の 倉庫建築物の被害である。この建築物は幅約 $70 \mathrm{~m} \times$ 奥 行き約 $40 \mathrm{~m} \times$ 高さ約 $30 \mathrm{~m}$ で，折板のスパンは約 $40 \mathrm{~m}$ である。この被害も固定ボルトの金属疲労によること が確認されている。断熱二重折板が固定ボルトに金属

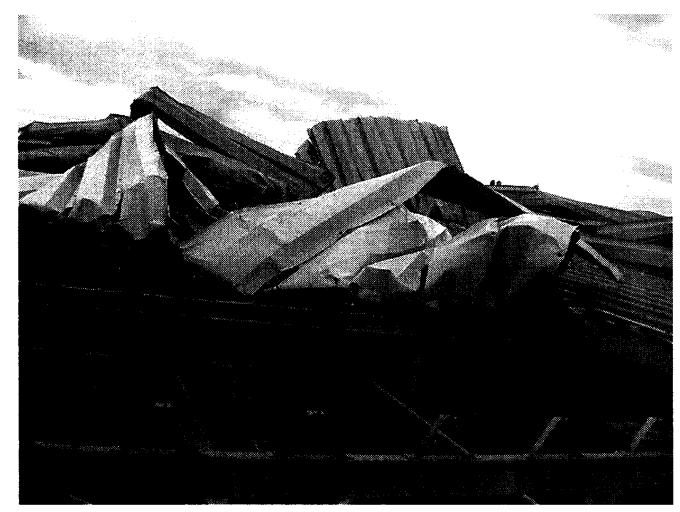

写真 5 神戸市の倉庫建築物の被害
疲労を生じさせやすいという訳ではないが，断熱仕様 は上側折板と下側折板との間に温度差を与えるので, それ:こよる金属板の伸縮量の差として生じるせん断力 ※ボルトが受け持つには力が大き過ぎるであろう。同 種の既存の屋根ではこの高ストレス低サイクル疲労の 痕跡がないかどうかを調査することが望ましい。

大熊, 河井, 西村らは写真 6 に示す台風 0418 号によ る山口情報芸術センターの被害を調查した。この被害 は屋根面積の約半分の鋼板製屋根ふき材が剥離・脱落 したものである。屋根ふき材はスパン $30 \mathrm{~m} \times$ 幅 $45 \mathrm{~cm}$, 厚さ $0.6 \mathrm{~mm}$ のガルバリウム鋼板で, 写真 7 に示す吊り 子を介してビスで端部付近ではピッチ $30 \mathrm{~cm}$ で高圧木 毛セメント板に，中央部ではピッチ $60 \mathrm{~cm}$ でモルタル 下地に固定されていた。屋根ふき材はケラバ付近から 剥れ始め, 連鎖的に被害が広がった。被害調査委員会 が設けられ，被害の原因は，鋼板の熱伸縮によるねじ 部の緩みと材料強度のばらつきが原因であると考えら れた。その他に直接の原因ではないが，この建築物は 特殊な形状をしているにも拘わらず体育館等の円弧屋 根の風力係数を用いていること，ケラバ部の端部から 屋根ふき材の下部に風が入るディテールであることの 妥当性にも疑問が出された。

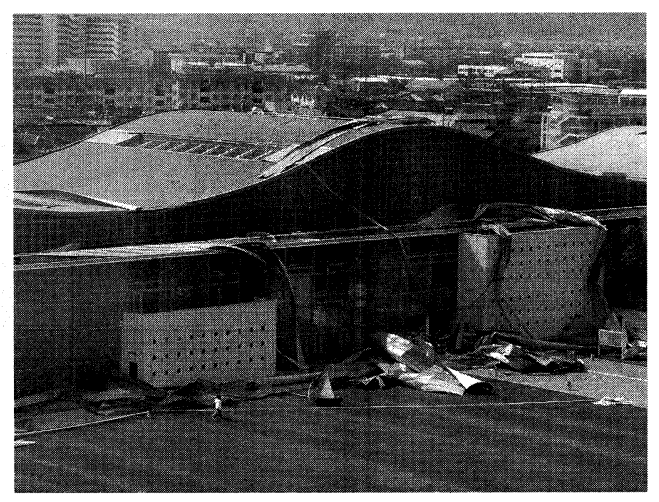

写真 6 山口情報芸術センターの屋根ふき材の被害 （山口大学藤川哲）

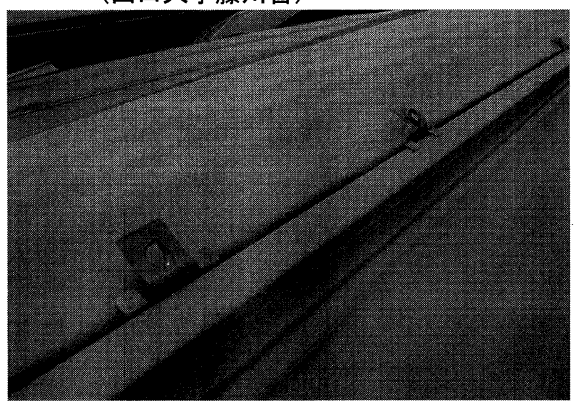

写真 7 飛散した屋根ふき材の吊り子 
出雲ドームは大断面構造用集成材による木質系立体 張弦アーチ構造テンション膜構造で, 厚さ $0.8 \mathrm{~mm}$ の膜 はガラン繊維をテフロン被覆している。このドームの 36 枚の膜のうち風にほぼ直交する面の 1 枚の膜が台風 0418 号の強風を受けて破けた被害（写真 8 , 写真 9) を, 谷池, 谷口, 西村が調査した。被害の原因は「テ フロン膜とテフロンコーティングされた押えケーブル の間に砂や土が入り, 竣工後 12 年間の風に膜と押えケ ーブルが砂や土を噛んだ状態で擦れ続けたために, 膜 のテフロンコーティングが剥げ，膜の強度が低下した ことによる」と考えられている。
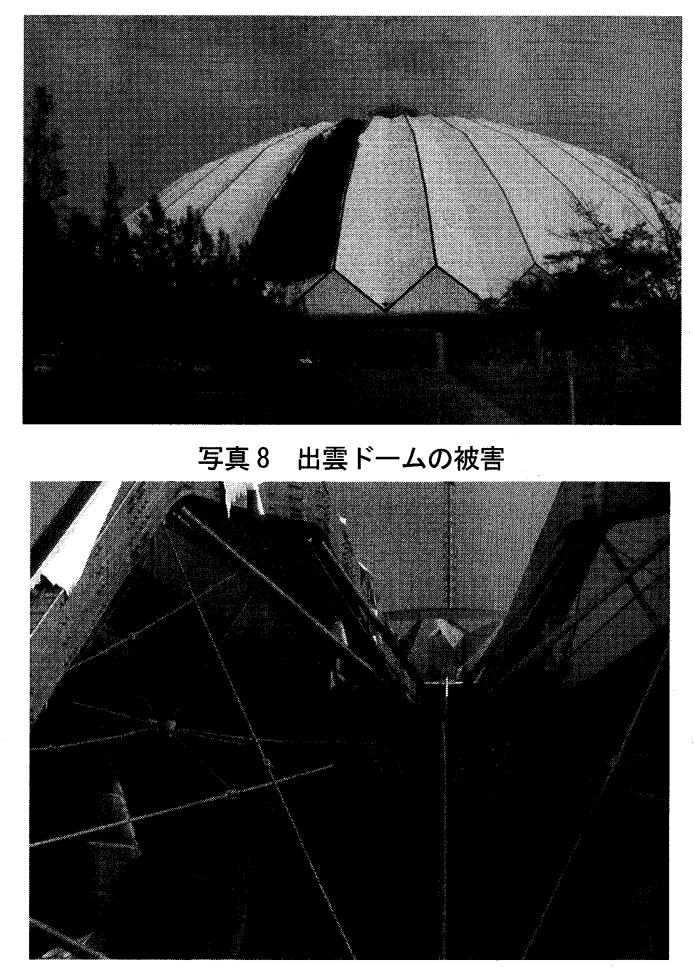

写真 9 出雲ドームの膜の破損

曹, 河井, 西村は台風 0418 号による山口県のきらら ドームのトップライトのガラスが破損した被害を調査 した。このドームはシステムパイプトラス膜構造で, 長軸 $157 \mathrm{~m} \times$ 短軸 $147 \mathrm{~m} \times$ 高さ $50 \mathrm{~m}$ の規模をもち, トッ プライトは直径 $28 \mathrm{~m}$ で膜面より $2.7 \mathrm{~m}$ の立ち上がりを もっている。ガラスは厚さ $20 \mathrm{~mm}$ の合わせガラスで, 写真 10 に示すように, 127 枚のうち 27 枚が風圧で破 損する被害を受けた。被害原因の特定には，ガラス単 体の強度だけでなくガラスの固定枠や治具の強度も含 めて検討する必要があると思われる。

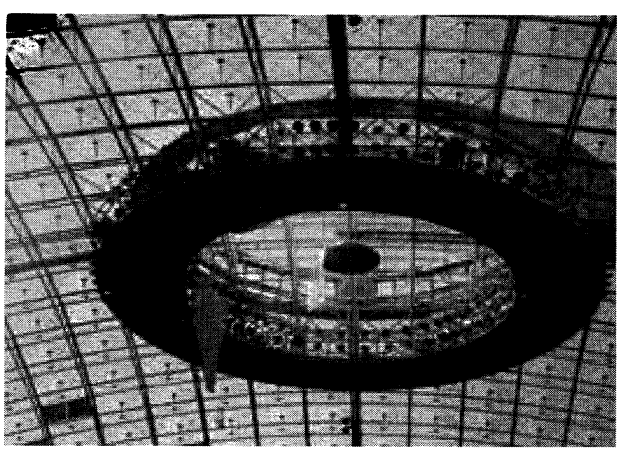

写真 10 きららドームのトップライトの被害

長尾と西村は台風 0406 号, 0410 号および 0423 号で 被害を受けた東かがわ市の大川体育館の被害を調査し た（写真 11，写真 12）。この建築物では，3 個の台風 で屋根の $3 / 4$ の金属板屋根ふき材が剥離する被害を受 けた。この体育館の屋根は ALC パネルの下地に屋根 ふき鋼板が瓦棒莫きで仕上げられており，瓦棒はアル ミニウム製先割れ釘で固定されていた。先割れ釘は打 ち込まれると ALC パネルの中で 2 つに割けて引抜き 力に抵抗する。被害はこの先割れ釘の多くが破断する ことで生じており，構法の妥当性に疑問が残る。この 点に関して香川県が被害調查委員会を設け, 改修の提 案を行った。

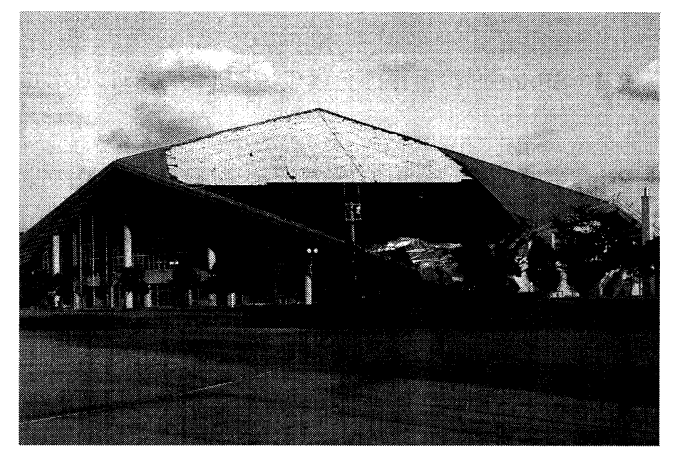

写真 11 大川体育館の被害

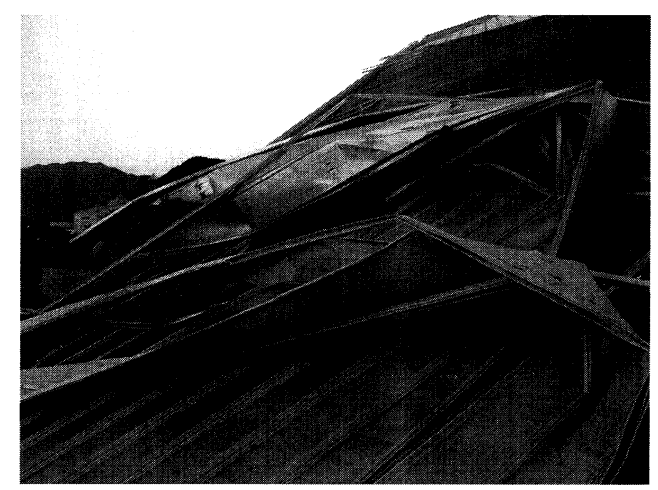

写真 12 大川体育館の屋根ふき材の剥離 
植松は台風 0418 号による北海道での被害を調查し た。写真 13 は江別市内の中学校の校舎の折板が強風で 吹き飛ばされた被害である。寒冷地ではコンクリート スラブの凍害を防止する目的で，コンクリートスラブ の上に屋根を置く「置き屋根構法」が多く見られる。 置き屋根もスラブ等に固定されるが，固定強度が不十 分な場合には写真の例のように飛散・脱落してしまう ことがある。植松は「寒冷地では台風被害を受けるこ とがあまりなかったため, 而風設計が十分になされて いないことが，多くの被害を発生した遠因となってい る」と述へ，寒冷地における耐風設計の普及の必要性 を強調している。

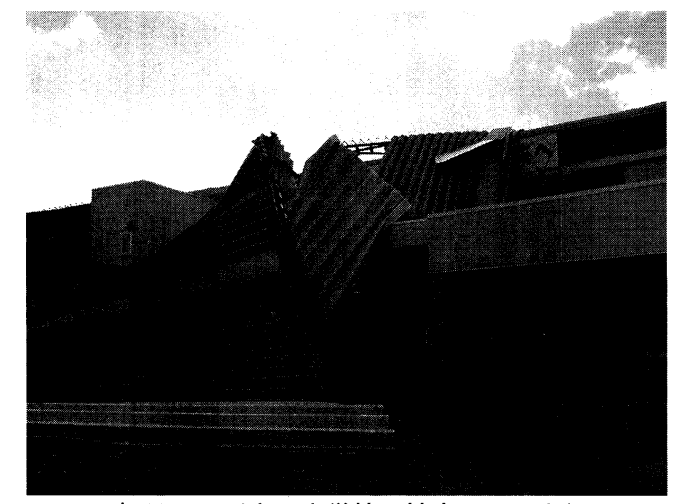

写真 13 江別市の中学校の被害（江別市役所）

\section{2 体育館の被害}

上述の東かがわ市の大川体育館の被害の他にも体育 館の屋根が被害を受けた例が多くある。写真 14 は台風 0418 号で被害を受けた長崎西高校の体育館の被害で, 前田, 友清, 渡邊によって調查された。

公立学校の体育館は周辺住民の緊急避難所として指 定されている建築物が多いが，体育館はスポーツ施設 として設計されており, 人命を守る避難所として設計 されているものではない。避難所として要求される建 築物の性能さえ明確になっていない。大空間をもつ公 共建築物を避難所として指定する場合の耐風設計のガ イドラインが必要であろう。なお，地震で天井が落下 した事故もあり, 避難所としての内外装材の耐震性能 も設計ガイドラインに含まれるべきである。

強風によって被害を受ける例が多いことは，巨大台 風の大災害時に周辺住民は安全な避難場所を失うこと を意味している。2004 年の台風シーズンの後, インタ ーネットで体育館の被害を検索しただけで, 全国で 30 校もの体育館が被害を受けていることが分かった。こ れは体育館の被害の一部であると考えられる。その中
には比較的軽微な被害も含まれるが，長時間継続する 強風の中で被害が拡大するかもしれないという不安を 避難者が抱くことは容易に想像できる。危険を賭して 二次避難先に移動するか, 被害が拡大しないことを期 待して留まるかという究極の選択は避難者には過酷で あろう。そうした状況を避けるために, 日本風工学会 では,「強風災害の防止に関する提言」3)を 2005 年 10 月 3 日に発表し, 緊急点検と定期点検を推奨している。

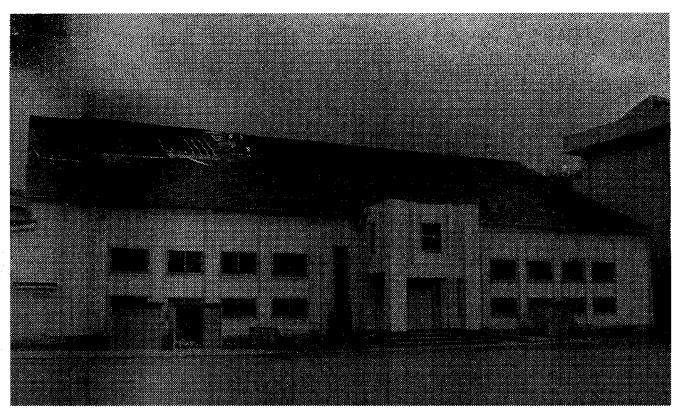

写真 14 長崎西高校体育館屋根の被害（長崎大学木村祥裕）

\section{3 一般家屋の被害}

住宅の強風被害部位には非常に多くの種類があり, 屋根ふき材の飛散, 空, トップライト, ドアなどの開 口部の破損, 外壁サイディング, 軒天井の剥離, 樋や アンテナの損傷など多岐にわたる。中には構造骨組が 損傷した例もある。松井, 田村, 奥田, 喜々津は台風 0422 号における静岡県伊東市の住宅の被害を調查し た (写真 15 , 写真 16 )。

これらの住宅被害は表 3 のような統計は調査される が, 原因の分析までには至っていないことが多い。住 宅は個々に構法が異なることと, 経年変化によって強 度が低下する割合が比較的大きいことから被害原因の 分析が困難であると考えられるが, 被害の総計は大き く，被害の分析を行う体制を整える必要があろう。損 害保険会社個々には, 保険金の請求時に提出される被 害状沉と被害金額のデータのストックがあるが，それ らの分析はなされておらず, 公表されていない。その 結果, 社会資本の中心である住宅の性能向上は, ひた すら業界の努力に求められるのみである。業界が住宅 部品の耐風性能の向上に取り組んだ例としては, 全日 本瓦工事業連盟等が瓦屋根標準設計・施工ガイドライ ンをまとめ, 建築基準法に準拠した瓦の緊結の仕様を 提案したものがある。

米国では FEMA が 1992 年のハリケーン Andrew や 2004 年のハリケーン Charley, Frances, Ivan, Jeanne の後, 
被害の分析を行って, 住宅の弱点部（屋根ふき材, 屋 根上の機械および電気装置, 軒天井, 空とドアなど） の改善の方向性を示し, 設計施工のガイダンスを提案 し, 公的教育の必要性まで言及した報告書 ${ }^{4)}$ を発表し ている。こうした取り組みがわが国でもできるかどう かを検討する必要があると思われ，本会が貢献できる 一つの場面であると考えられる。

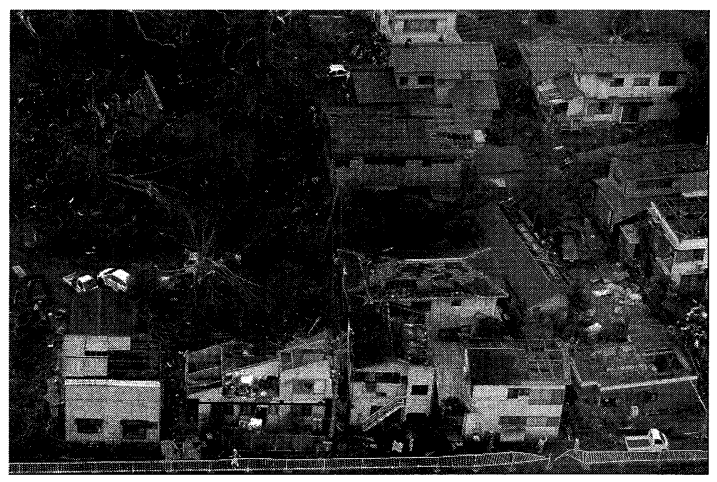

写真 15 伊東市の住宅被害（読売新聞社）

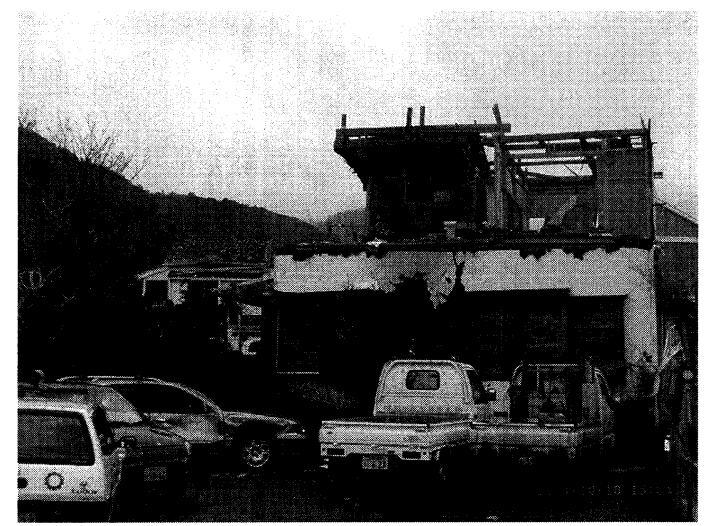

写真 16 小屋組が破壊された住宅被害

表 3 台風 0418 号の住宅被害

\begin{tabular}{|l|r|r|r|r|}
\hline \multirow{2}{*}{} & \multicolumn{4}{|c|}{ 住家被害件数 (参考・消防庁調べ) } \\
\cline { 2 - 5 } & \multicolumn{4}{|c|}{ (2005.3.23 現在) } \\
\cline { 2 - 5 } & $\begin{array}{l}\text { 全壊・半 } \\
\text { 壊 }\end{array}$ & $\begin{array}{c}\text { 一部 損 } \\
\text { 壊（棟） }\end{array}$ & $\begin{array}{l}\text { 床上浸 } \\
\text { 水(棟) }\end{array}$ & $\begin{array}{l}\text { 床下浸 } \\
\text { 水(棟) }\end{array}$ \\
\hline 北海道 & 229 & 8,450 & 79 & 40 \\
\hline 東北 & & 397 & & 1 \\
\hline 関東・甲信越 & & 26 & & \\
\hline 中部・北陸 & & 180 & & 2 \\
\hline 近畿 & 19 & 1,023 & 51 & 333 \\
\hline 中国 & 838 & 30,818 & 1,305 & 5,317 \\
\hline 四国 & 27 & 811 & 108 & 743 \\
\hline 九州 & 415 & 23,360 & 27 & 190 \\
\hline 合計 & 1,528 & 65,065 & 1,570 & 6,626 \\
\hline
\end{tabular}

台風の進路の右側に位置する地域は風が強くなる という傾向は広く報道され，認識されるようになった が，安直にそのことだけを強調するのは危険であると 前田, 友清は注意を発している。図 1 に示すように, 台風 0423 号は九州の南海上を通過し,九州には上陸し ていないが, 台風経路から $300 \mathrm{~km}$ 以上離れた九州北部 （台風進路の左側）地域で $30 \mathrm{~m} / \mathrm{s}$ から $60 \mathrm{~m} / \mathrm{s}$ の最大瞬 間風速を記録し,佐賀県では狭い地域に写真 17 に示す ような 1,400 戸以上の住家被害が集中して発生した。 図 1 は台風の経路の近くより遠く離れた場所のほうが 被害が多い結果を示しており，これまでの常識と異な る。この原因は山越えの気流が一部で強風となったも のと推測されている。平野の周りに山岳をもつわが国 の地形がこれと似た状況を生み出す可能性は多くの場 所であると思われるが, そうした場所には強風の伝承 もあるので，台風の中心が遠くにあっても注意をして おく必要があろう。

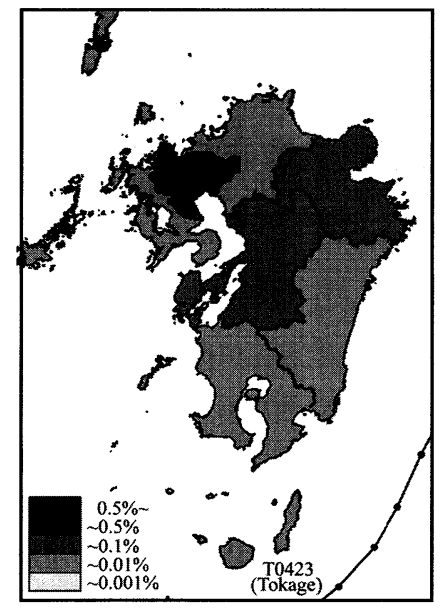

図 1 台風 0423 号による九州の住宅被害分布

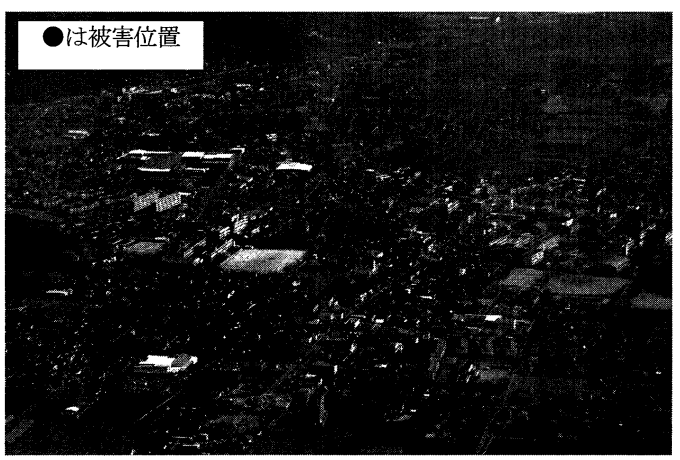

写真 17 台風 0423 号による佐賀県子城町の被害 


\section{4 歴史的建造物の被害}

歴史的建造物はこれまで風雪に耐えて現在に至っ ているので, 相当の耐風性能は有していると思われる が，性能の劣化は避けられない。有形文化財，民俗文 化財, 記念物, 伝統的建造物群からなる文化財につい て, 文化庁文化財部伝統文化課で集計された 2004 年の 台風による被害件数のうち, 歴史的建造物に関連する 被害は表4に示すように約 680 件にのぼった。その内, 約 $80 \%$ が強風による被害である。

表 4 原因別の文化財建造物被害件数

\begin{tabular}{|c|c|c|c|c|}
\hline 台風 & 全件数 & 風による & 土砂による & 水による \\
\hline 6 号 & 33 & 30 & 3 & 0 \\
10 号 & 3 & 2 & 0 & 1 \\
15 号 & 12 & 12 & 0 & 0 \\
16 号 & 151 & 135 & 6 & 10 \\
18 号 & 262 & 232 & 7 & 23 \\
21 号 & 22 & 14 & 6 & 2 \\
22 号 & 47 & 23 & 23 & 1 \\
23 号 & 153 & 113 & 30 & 10 \\
\hline 合計 & 683 & 561 & 75 & 47 \\
\hline
\end{tabular}

写真 18 , 写真 19 は台風 0418 号で広島県宮島の厳島 神社の国宝左楽房が崩壊した様子である。厳島神社で は台風 9119 号，9918 号でも被害を受けるなど，これ までも度々台風被害を被っている。厳島神社のある宮 島は広島湾の中にあり，急峻な山と谷が複雑に入り組 んだ地形を持っている。厳島神社は北西の入り江の奥 に位置し，南側と東側は高い山を背にしており自然の 要害となっている。ただし，背後の山の鞍部から強い 下降流が厳島神社に吹き降ろした可能性も考えられて いる。なお，本社拝殿，西迴廊，客神社祓殿の檜皮屋 根のめくれ, 能舞台の軒瓦の飛散, 能舞台の軒瓦およ び床，土台にも被害があった。丸山，河井，益田，田 村，松井は「歷史的な建造物である厳島神社の復旧に 際してはこれまでと同じ建て方で再建されると考えら れるが，台風襲来時には事前に筋交で補強するなどの 対策が必要である」と提案している。而風工学の知識 が貴重な歴史的建造物の再建に活かされる社会的な仕 組みを考える必要があろう。

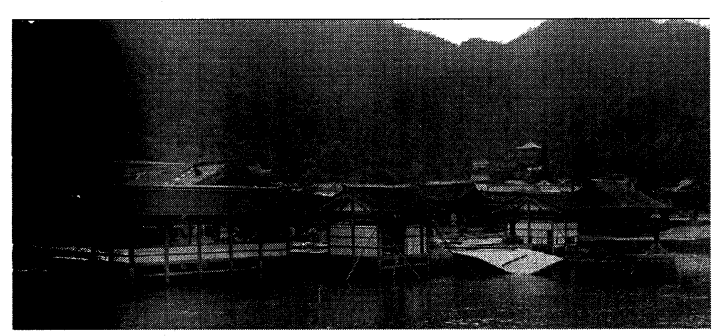

写真 18 厳島神社の被害

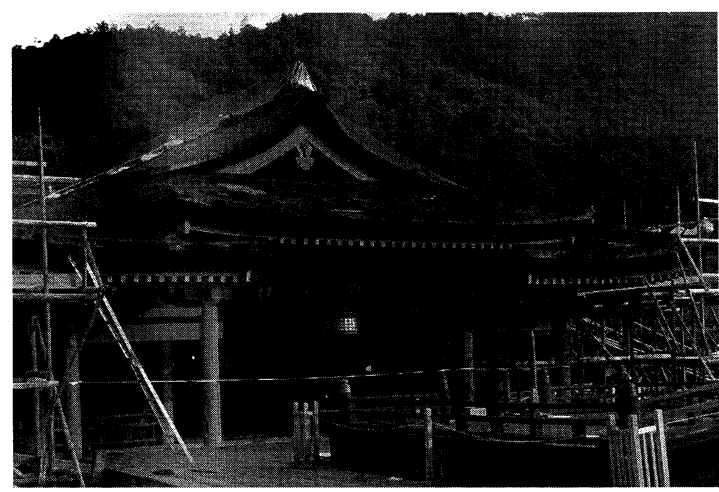

写真 19 厳島神社本殿の被害

植松，松井は写真 20 に示寸北海道の鰊御殿の台風 0418 号での被害を調查した。この建築物は日本海を望 む岬の先端に移設され, 周辺の地形の影響で風が増速 されたと考えられている。その他, 姫路城, 熊本城, 出雲神社など多くの歴史的建造物が台風で被害を受け た。これらの歴史的建造物は構法や材料を従来のもの と変えてしまうと, その価值を著しく損なうので, 現 状復帰を原則としている。これまで，歴史的建造物を 保全する関係者と耐風工学の専門家との接点は少なく, 被害の全体像や現在の個々の耐風性能もほとんど分か っていないのが現状である。

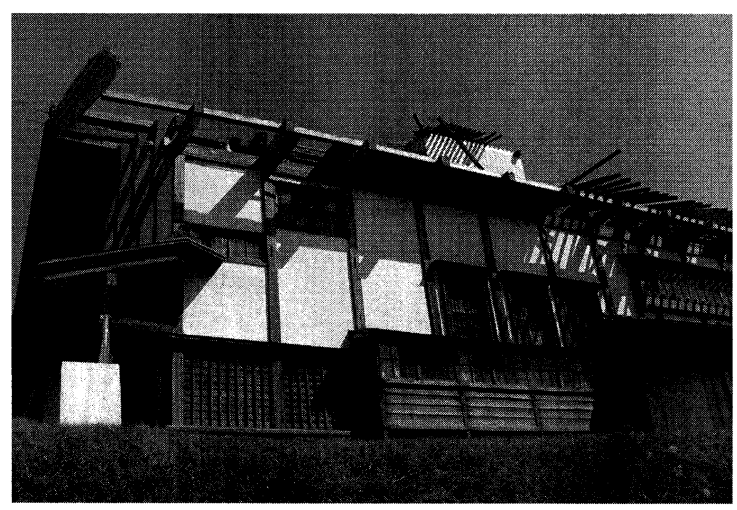

写真 20 鰊御殿の被害（小樽市役所） 


\section{5 風力発電施設の被害}

わが国においても風力発電設備が急速に設置され ており, 台風の強風による被害が報告されている。風 車は元々風の強いサイトに建設されるため, 他の建築 物や構造物より風の影響を受けやすい。

石原は写真 21 に示寸台風 0416 号で被害を受けたブ レード先端が折れた事故を示し,「タワー近傍のせん断 層に起因する乱流渦による渦励振や強制的振動の可能 性」を指摘し，金属疲労も考慮する心゙きであるとして いる。また写真 22 に示す基礎の被害から, ペデスタル の耐風設計指針を作成する必要があるとしている。別 の風車の事故では，モニター用の風速計が破損したた めに風車の制御が不可能になった例やナセルのカバー が破損した例を挙げ，細部に至る十分な設計の必要性 を指摘している。海外で実績があっても，世界最大級 の強風を生じる台風が襲来するわが国の害情に合わせ て，適切に耐風設計をし直すべきであると思われる。

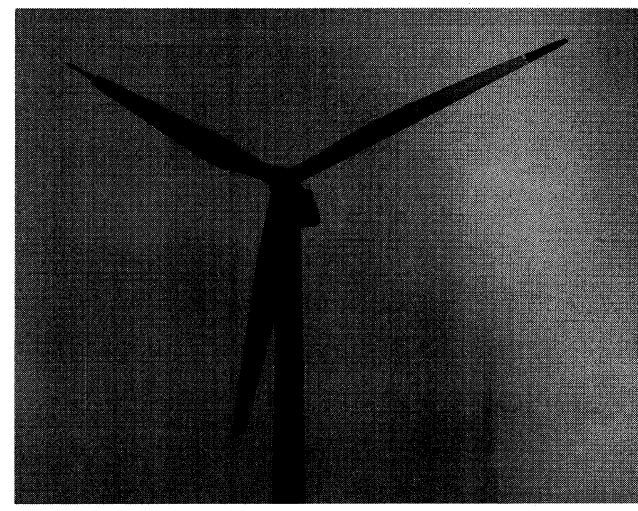

写真 21 風車のブレードの被害

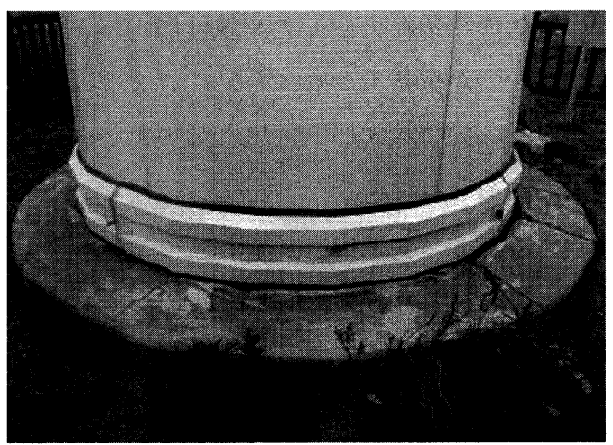

写真 22 風車の基礎コンクリートの亀裂

\section{6 農業施設の被害}

プラスチックハウス等の農業施設は強風に対して 充分な強度をもたないことが多い。人の生命を守る建 築物より重要度が低くまた供用期間も短いため, 耐風
性能は低く見積もられている。また，その風荷重は明 確にされていないことが多い。投入する資金と被害に よって被る損害額および農業災害補償制度で支払われ る共済金とのバランスで最適な施設の計画ができる手 法を開発する必要があろう。

また森山，佐瀬，前田は「プラスチックハウスの強 風対策の一つとして，台風シーズンを避けて被覆材を 展張していることが多い。そのため，季節はずれの強 風や突風に対して脆弱である。2004 年には予想外の時 期に強風が吹いたため，温室の被害額は大きく，被害 地域も全国的な範囲に及んだ」と述へ，台風以外の強 風についても注意すべきであるとし，表 5 の集計を示 している。写真 23 はプラスチックハウスの強風被害の 例である。

表 52004 年の強風による営農施設の被害実態 （1 億円以上の被害のみ・速報值）

\begin{tabular}{|c|c|c|c|}
\hline 災害名 & 時期 & $\begin{array}{c}\text { 被害額 } \\
\text { (百万円) }\end{array}$ & 被災した主な都道府県 \\
\hline 台風0406号 & 6月 & 617 & 和歌山、高知、滋賀 \\
\hline 台風0410号 - 0411号 & 7月 & 198 & 高知 \\
\hline 台風0415号・前線 & 8月 & 1,524 & 山形、秋田、香川 \\
\hline 台風0416号 & 8月 & 5,148 & 宮崎、高知、兵庫 \\
\hline 台風0418号 & 9 月 & 23,552 & 北海道、山口、福岡 \\
\hline 台風0421号 & 9月 & 870 & 愛媛、鹿児島 \\
\hline 台風,0422号 & 10月 & 344 & 静岡 \\
\hline 台風,0423号 & 10月 & 5,551 & 兵庫、京都、岡山 \\
\hline 強風 & 11月 & 320 & 岩手、青森 \\
\hline 強風 & 12月 & 377 & 静岡、千葉、三重 \\
\hline
\end{tabular}

* 営農施設は、ビニールハウスの他に、畜舎、樹体、家畜を合を。

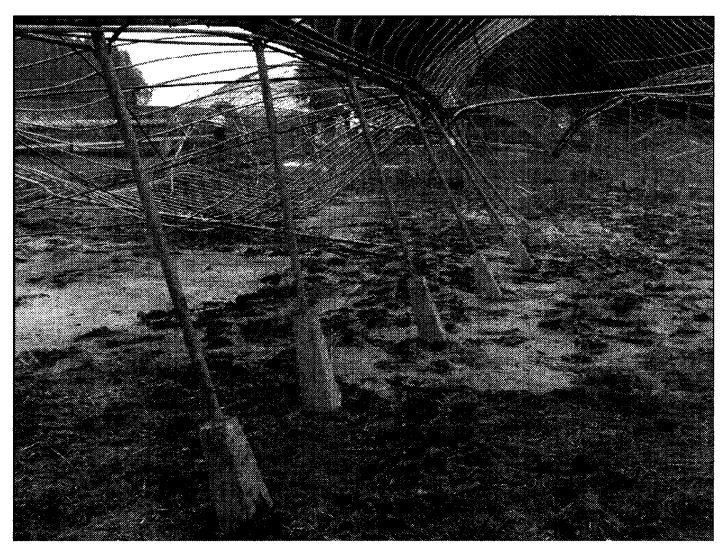

写真 23 プラスチックハウスの被害

\section{7 仮設構造物の被害}

仮設構造物の中で，足場は施工中の飛来・落下物災 害等の防止を目的として前面にシート等を張る場合が 多いが，強風によって倒壊する事故が多く発生してい る。大幢は「倒壊した足場はすぐに撤去され，その事 
実さえ報告されていないことがあり，現状の把握が困 難である」と, 被害を把握する段階の問題点を指摘し ている。また事前に強風の発生が予想される場合は, シートの取り外しや巻き取りなどの強風対策が決めら れているにも拘わらず，「実際には，台風のように数日 前から強風が予想されている場合でも，多くの現場で は強風対策が行われていないと, 安全対策の実行が 十分でないと指摘している。したがって，台風以外で も低気圧などによる突風によって仮設構造物が崩壊す る被害が多く発生している。写真 24 は解体工事の足場 が突風で倒壊した例である。

なお，田村 ${ }^{5)}$ は仮設構造物の設計に当たって，仮設 物の短い供用期間を基準にして設計風速の再現期待值 を設定する方法に疑問を呈している。個々の仮設物の 供用期間は短くても，都市の中にはそのような仮設物 はいつも存在しており, それらを群としてとらえたと きには個の供用期間に基づいて決定される設計風速は 適切ではないと主張している。

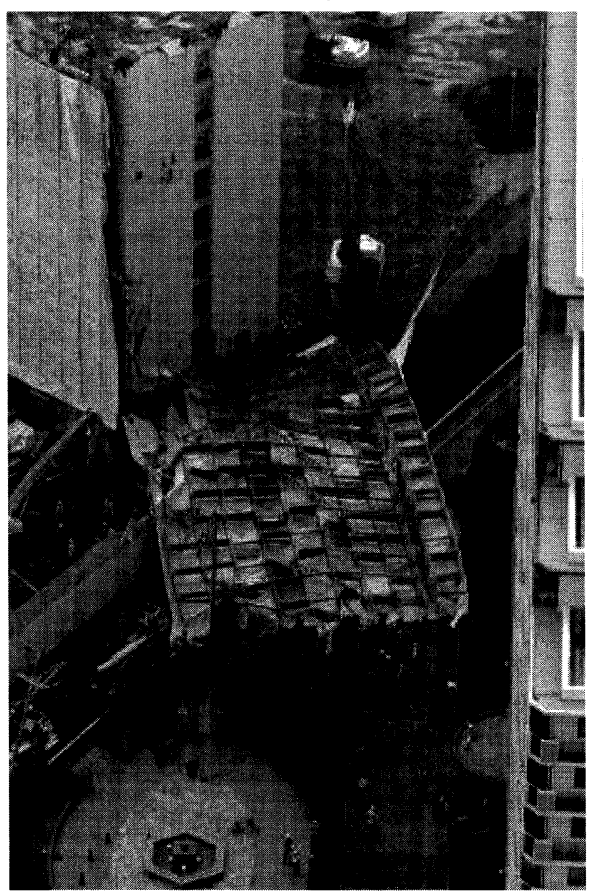

写真 24 足場の倒壊事故

\section{8 その他の施設}

長尾, 植松はカーポートや広告塔の被害を調査した。 写真 25 はカーポートの被害の例で, 多くのカーポート のパネルの飛散や屋根支持材の被害が報告されている。 カーポートのパネルの性能規定はJIS A 6604 「金属製 簡易車庫用構成材」に含まれておらず，風荷重はパネ
ルではなくその支持構造材に負担させて確認する試験 方法になっているなど，製品規格の不整備の問題が指 摘されている。

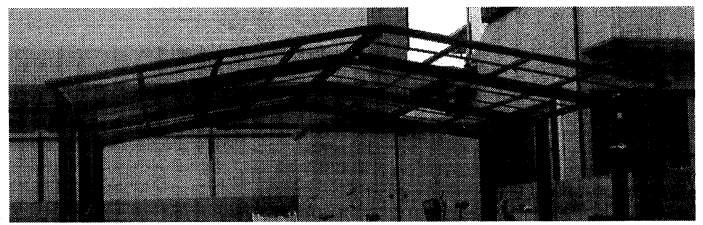

写真 25 カーポートの屋根ふき材の飛散例

写真 26 は大型広告塔の倒壊の様子で, 転倒した広告 塔は近隣の民家に直撃し，民家も破損させた。この例 では鋼管柱が根元で曲げ破壊しており，強度不足が指 摘された。小さい看板は至るところで被害を受けてい るが，損傷によって他に危害を与える恐れのある工作 物は適切に耐風設計を行う必要がある。

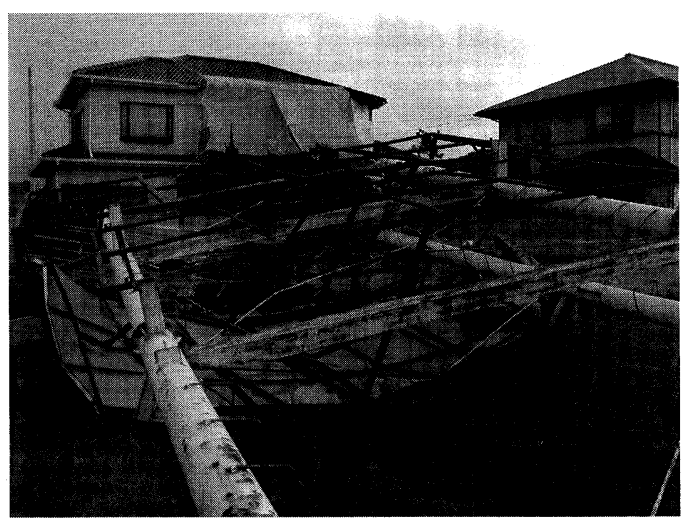

写真 26 大型広告塔の倒壊

\section{4. 竜巻・突風による被害}

2004 年には竜巻やダウンバーストなどによる被害 も多く報告されている。前田，友清，田村，木村，松 井，奥田，喜々津らは 6 月 27 日の佐賀県の竜巻を，松 井，田村は 6 月 29 日の杤木県の突風を，吉田，田村は 9 月 29 日の豊橋での竜巻を, また松井，田村，斉藤は 10 月 22 日の北海道での竜巻を調査した。これらの被 害状況を写真 27 写真 31 に示す。

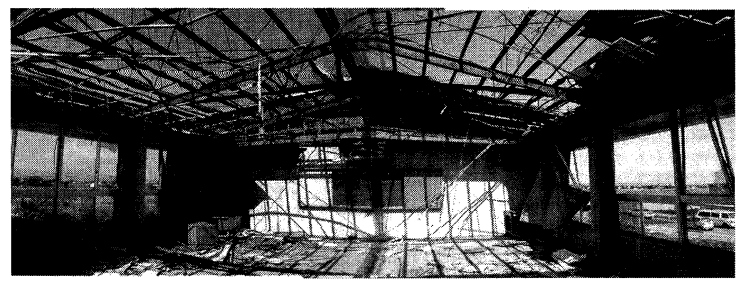

写真 27 佐賀県の竜巻による農協施設屋根の被害 


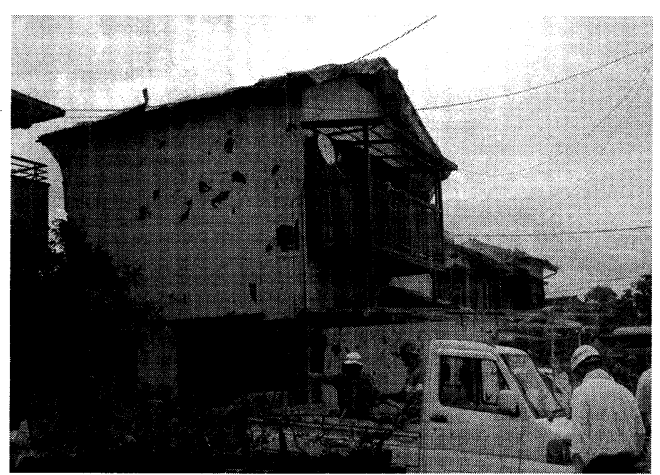

写真 28 佐賀県の竜巻での飛来物による住宅の被害

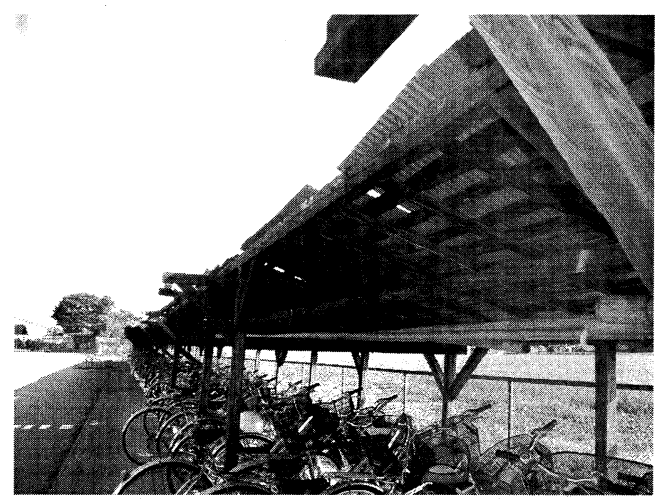

写真 29 杤木県の突風による駐輪場の庇の損傷

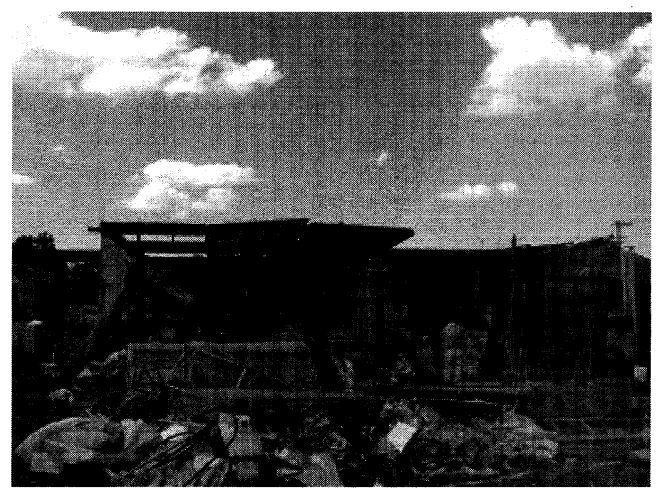

写真 30 豊橋市の竜巻による倒壊した作業小屋

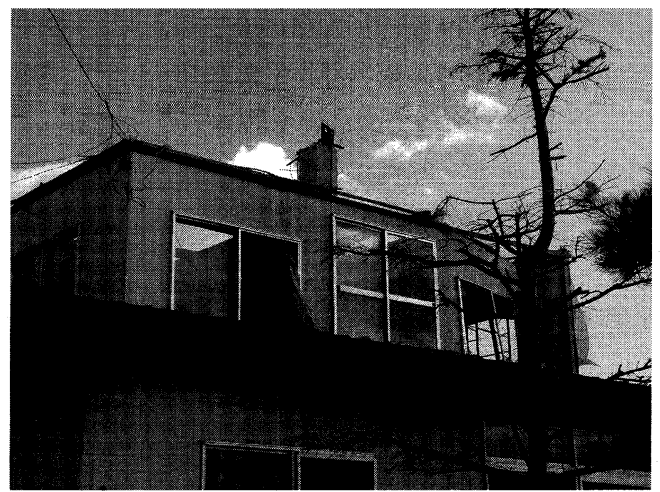

写真 31 北海道の竜巻による住宅の被害
竜巻やダウンバーストは面的な広がりは小さいが, 写真のように, 強い破壊力をもつ。その発生は局所的, 突発的であり, 現時点では予測が困難である。広い観 測網の整備によってこれらの発生の正確な予測が期待 されるが，予測されたとしても，これらの強風による 構造物の被害は免れ得ないであろう。したがって, こ れらの現象によってもたらされる荷重効果が台風など を想定した現行の耐風設計で対応できるかどうかの解 明が待たれよう。また, 竜巻では多くの飛散物が発生 することが知られている（写真 28）が, 飛来物に抵抗 する建築物の性能は現在要求されていない。ただし, 重要な施設では飛来物に対する性能を考慮した設計も 必要とされることがあり, 今後の課題と言える。

\section{5. おわりに}

2004 年には, 過去最多の上陸台風によって各地で多 くの被害が発生した。風災害研究会委員と関係者の調 査によって, それらの被害の一部が明らかになり, 原 因究明も行われた。ただし, 被害の全容を把握するシ ステムができていないため, 断片的な情報の寄せ集め になっている恐れもある。特に被害による損失額は集 計されていないのが現状で, 全体的な衝撃の大きさの 把握がなされていないことが強風被害についての一般 の関心の低さを招いていると考えられる。また個々の 被害の原因分析は，同様の構法・材料をもつ構造物の 安全性にとって極めて有益な情報であるので, それら の取りまとめと公表は重要である。さらに, 日本風工 学会はそれらの対策案の提言, 規基準の整備について も貢献できる能力を有すると考えられる。

\section{参考文献}

1) 日本風工学会風災害研究会 : 2004 年の強風災害に 関する調査報告書, 2005 年 5 月

2) 日本建築学会:2004年の強風被害とその教訓, 2006 年 3 月

3) 田村幸雄 : 強風災害の防止に関する提言, 日本風 工学会誌, No.105, pp.423-424，2005 年 10 月

4) FEMA490: Summary Report on Building Performance 2004 Hurricane Season, March 2005.

5) 田村幸雄: 強風災害加ら学ぶもの, 建築雑誌, 2005 年 2 月号, pp.16-17 